\title{
The impact of the pandemic on early career researchers: what we already know from the internationally published literature
}

Eti Herman; David Nicholas; Anthony Watkinson; Blanca Rodríguez-Bravo; Abdullah Abrizah; Chérifa Boukacem-Zeghmouri; Hamid R. Jamali; David Sims; Suzie Allard; Carol Tenopir; Jie Xu; Marzena Świgoń; Galina Serbina; Leah Parke Cannon

How to cite this article:

Herman, Eti; Nicholas, David; Watkinson, Anthony; Rodríguez-Bravo, Blanca; Abrizah, Abdullah; BoukacemZeghmouri, Chérifa; Jamali, Hamid R.; Sims, David; Allard, Suzie; Tenopir, Carol; Xu, Jie; Świgoń, Marzena; Serbina, Galina; Cannon, Leah Parke (2021). "The impact of the pandemic on early career researchers: what we already know from the internationally published literature". Profesional de la información, v. 30, n. 2, e300208. https://doi.org/10.3145/epi.2021.mar.08

Manuscript received on $26^{\text {th }}$ January 2021 Accepted on $29^{\text {th }}$ March 2021


Eti Herman

https://orcid.org/0000-0001-8526-9081

CIBER Research Ltd

Newbury, Berkshire, RG147RU, UK

University of Haifa

Abba Khoushy Ave 199

Haifa, 3498838, Israel

eherman@univ.haifa.ac.il

Anthony Watkinson

https://orcid.org/0000-0002-2317-6557

CIBER Research Ltd

Newbury, Berkshire, RG147RU, UK

anthony.watkinson@btinternet.com

Abdullah Abrizah

https://orcid.org/0000-0002-8224-5268

University of Malaya

Faculty of Arts and Social Sciences

Department of Library \& Information

Science

50603 Kuala Lumpur, Malaysia

abrizah@um.edu.my

\section{Hamid R. Jamali}

https://orcid.org/0000-0003-1232-6473

Charles Sturt University

School of Information Studies

Locked Bag 588, Wagga Wagga

NSW 2678, Australia

h.jamali@gmail.com

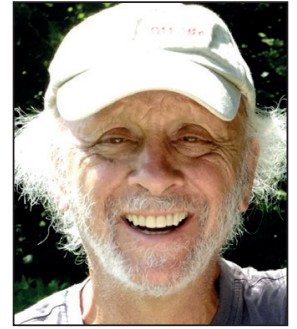

David Nicholas $\square$

https://orcid.org/0000-0001-8046-2835

CIBER Research Ltd

Newbury, Berkshire, RG147RU, UK

dave.nicholas@ciber-research.com

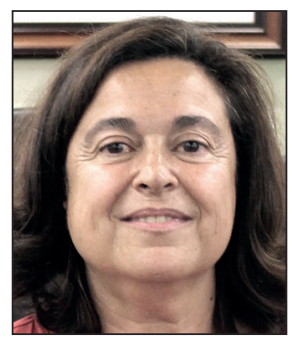

Blanca Rodríguez-Bravo

https://orcid.org/0000-0002-9476-7602

Universidad de León

Área de Biblioteconomía y Documentación

Campus de Vegazana, s/n.

24071 León, Spain

blanca.rodriguez@unileon.es

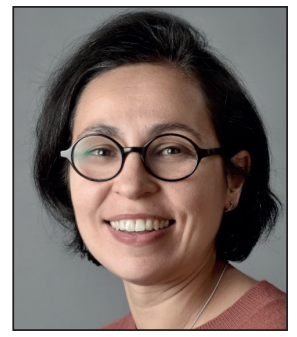

Chérifa Boukacem-Zeghmouri https://orcid.org/0000-0002-0201-6159

Université de Lyon

Department of Computer Science

69100 Villeurbanne, France

cherifa.boukacem-zeghmouri@univ-lyon1.fr

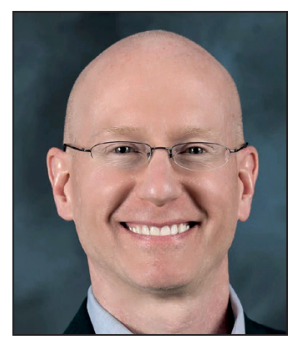

\section{David Sims}

https://orcid.org/0000-0003-1916-5617

University of Tennessee

School of Information Sciences

1345 Circle Park Drive, 423

Knoxville, TN 37996-0341, USA

dsims7@utk.edu 


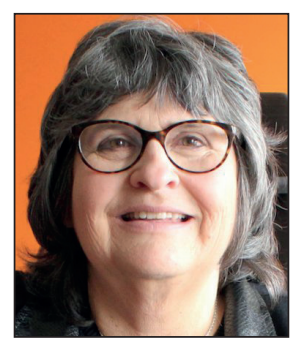

\section{Suzie Allard}

https://orcid.org/0000-0001-9421-3848

University of Tennessee

School of Information Sciences

1345 Circle Park Drive, 423

Knoxville, TN 37996-0341, USA

sallard@utk.edu

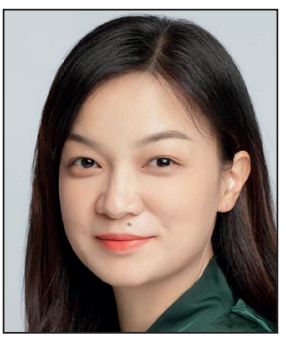

\section{Jie Xu}

https://orcid.org/0000-0002-9820-8066

Wuhan University

School of Information Management

Hubei 430072, Wuhan, China

xuj@whu.edu.cn

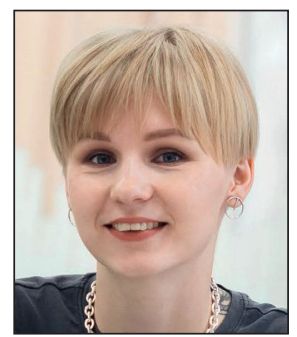

\section{Galina Serbina}

https://orcid.org/0000-0003-0196-6010

Tomsk State University

TSU Research Library

Lenin st. 34a, 634050 Tomsk, Russia

serbina@lib.tsu.ru

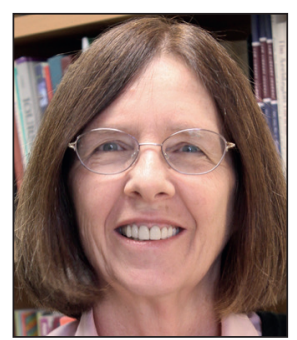

\section{Carol Tenopir}

https://orcid.org/0000-0002-9056-8251

University of Tennessee

School of Information Sciences

1345 Circle Park Drive, 451

Knoxville, TN 37996-0341, USA

ctenopir@utk.edu

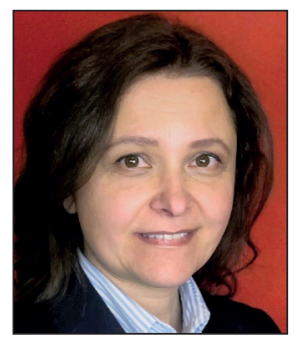

\section{Marzena Świgoń \\ https://orcid.org/0000-0003-3600-8349}

Uniwersytet Warminsko-Mazurski

Wydział Humanistyczny

10-719 Olsztyn, Poland

marzena.swigon@uwm.edu.pl

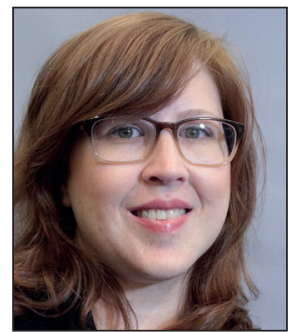

Leah Parke Cannon

https://orcid.org/0000-0001-5417-6472

University of Tennessee

School of Information Sciences

1345 Circle Park Drive, 451

Knoxville, TN 37996-0341, USA

Icannon8@vols.utk.edu

\section{Abstract}

In order to take account of the impact of the pandemic on the already changing scholarly communications and work-life of early career researchers (ECRs), the 4-year long Harbingers study was extended for another two years. As a precursor to the study (featuring interviews and a questionnaire survey), currently underway, an analytic review of the pertinent literature was undertaken and its results are presented here. The review focuses on the challenges faced by ECRs and how these compare to the ones more senior researchers have to tackle. In the examination of the literature three general questions are posed: Q1) What are the identifiable and forthcoming impacts of the pandemic-induced financial pressures felt in the Higher Education sector on ECRs' employment and career development prospects? Q2) What are the identifiable and forthcoming pandemic-associated disruptions in the pace/focus/direction of the research undertaking? Have any disruptions been predicted to exert an impact on ECRs' research activities, and if so, with what scholarly consequences? Q3) How is the work-life of ECRs shaping up under the virus-dictated rules of the 'new normal' in the research undertaking? What challenges, if any, arise from the changes in practices identified, and what might their potential consequences be for ECRs? The broad conclusion of the study is that the literature leaves little room for doubt: junior researchers are already disproportionally affected by and bear the burden of the ongoing pandemic-incurred hardships and they are likely to remain similarly impacted when more trials, still unfolding, materialise.

\section{Keywords}

Covid-19; Pandemic; Restrictions; Lockdowns; Early career researchers; Junior researchers; Young scholars; ECR; Literature review; Prospects; Employment; Career development; Challenges; Financial problems; Future; New normal; Female researchers; Women researchers; Scholarly work.

\section{Funding and acknowledgements}

This paper comes from the Harbingers-2 project: Early career researchers and the pandemic: a study on changing ECRs' employment status, careers and scholarly communication behaviour and attitudes. The project represents a collaboration between researchers at Ciber Research and the University of Tennessee, and includes researchers from Tomsk State University, University of Malaya, Wuhan University, Universidad de León, Charles Sturt University, University of Warmia and Mazury, Université de Lyon and the University of Haifa. It is funded by the Alfred P. Sloan Foundation. The Alfred P. Sloan Foundation is a philanthropic, not-for-profit grant-making institution based in New York City. Established in 1934 by Alfred Pritchard Sloan Jr., then-president and chief executive officer of General Motors, the foundation makes grants in support of original research and education in science, technology, engineering, mathematics, and economic performance. For more information about the Alfred P. Sloan Foundation, visit: http://www.sloan.org.

For more details on the Harbingers-2 project see http://ciber-research.com/harbingers-2 


\section{Introduction}

The Covid-19 pandemic, which has the world's entire population under its thrall, poses massive challenges to the international scholarly community, too. Unavoidably, perhaps, for it falls upon researchers to enable humankind to deal with the pandemic-induced, potentially life-threatening, but at least life-changing disruptions that have been taking place for quite some time now. Scientists and scholars are the ones who shoulder much of the burden of the fight for global health and well-being, whether directly, by understanding the virus and finding the ways and means of battling it successfully, or indirectly, by exploring its many economic, societal, emotional and practical impacts and determining how best to mitigate them. Vitally important, if taxing, their missions are then, made all the more demanding by the unfamiliar, often unprecedented circumstances in which research is conducted these days. Indeed, the environment in which today's research is undertaken is fashioned by need-of-the-hour restrictions, from financial pressures, which curtail universities' capabilities to maintain normal levels of activity, to lockdowns and social-distancing, which dictate the partial or even complete suspension of many lab- and field- based research activities and a general shift to home-based, remote working practices.

It falls upon researchers to enable humankind to deal with the pandemic-induced, potentially life-threatening, but at least life-changing disruptions that have been taking place for quite some time now... whether directly, by understanding the virus and finding the ways and means of battling it successfully, or indirectly, by exploring its many economic, societal, emotional and practical impacts and determining how best to mitigate them

It is in these critical days of crisis and truly unparalleled uncertainty that today's recent entrants to academe set out to navigate their career paths and build their scholarly identity. Even in the best of times it is no mean feat for early career researchers (ECRs) ${ }^{1}$ to establish themselves in the competitive world of academia, whilst trying to accommodate the demands of a new role in their discipline, institution and peer group (Vatansever, 2020). However, if ECR life has forever been fraught with difficulties that render it a particularly challenging, vulnerable and precarious experience, it is feared to become much more so now in the pandemic-incurred new realities of the research undertaking. Indeed, as a group of scientists warn, calling for swift action,

"the consequences of this crisis will disproportionately impact early-career scientists; especially those from communities historically underrepresented, disadvantaged and/or discriminated" (Maas et al., 2020, p. 997).

In fact, it is a recurrent theme in the ongoing speculations as to the future of the research endeavour that the current cohort of neophyte researchers might even turn out to be a lost generation, with an ensuing danger of talent implosion (Baker, 2020a; Cardel; Dean; Montoya-Williams, 2020; Radecki; Schonfeld, 2020).

It is yet to be comprehensively and robustly established how ECRs fare in this era of major transitions in the scholarly environment, which is what we have set out to do in a longitudinal international study, currently underway. Funded by the Alfred P. Sloan Foundation, the study is being conducted by CIBER Research in the UK, together with the University of Tennessee Center for Information and Communication Studies in the US.

https://sloan.org

http://ciber-research.eu/CIBER_projects.html

https://cics.utk.edu

It has collaborating university partners from China, France, Poland, Malaysia, Spain and Russia. However, the growing body of expert and educated prognostications and the first studies into the impacts of Covid-19 on the research enterprise already coalesce to paint a picture of significant challenges that today's ECRs face worldwide. The review of the pertinent literature on the topic, presented here, focuses, therefore, on the unfolding developments common to many countries, as reported in English language publishing venues targeting international audiences. Thus, it takes a discerning look at a host of studies, reports and deliberations to establish what is already known and/or predicted to be the consequences of the pandemic for the scholarly community, in general, and ECRs, in particular, via addressing the following questions:

- What are the currently identifiable and potentially forthcoming impacts of the pandemic-induced financial pressures felt in the Higher Education (HE) system on ECRs' employment position and career development prospects?

- What are the currently identifiable and potentially forthcoming pandemic-associated disruptions in the pace/focus/ direction of the research undertaking? Have these disruptions, if any, exerted/been predicted to exert an impact on ECRs' research activities, and if so, with what scholarly consequences for them?

- How is the work-life of ECRs shaping up under the virus-dictated rules of the 'new normal' in the scholarly undertaking? What challenges, if any, arise from the changes in practices identified, and what might their potential scholarly consequences be for ECRs? 


\section{Embarking upon an academic career amid the pandemic-wrought financial crisis in Higher Education}

\subsection{Background and context: the rocky road to a tenured academic position}

Long before Covid-19 made its appearance, the process of becoming a full-fledged member in the scholarly community had already been depicted as a long and arduous procedure, rendered as such mainly by the strong competition in most countries for the limited number of tenure-track academic positions available (Bennion; Locke, 2010; Brechelmacher; Park; Ates; Campbell, 2015; Castellacci; Viñas-Bardolet, 2020; McQuarrie; Kondra; Lamertz, 2020; National Academies, 2014; Petsko et al., 2014; Powell, 2015; Vatansever, 2020). Indeed, with the number of permanent faculty positions failing to keep track with the growing number of newly-minted PhD holders aspiring to join the ranks of academics (Maher; Sureda-Anfres, 2016), not even the fast acquisition of a massive scholarly capital, in terms of traditionally-defined stellar research achievements, has been able to guarantee the successful securing of a tenured position (Xing et al., 2019). Instead, for quite a few years subsequent to the award of a doctoral degree, ECRs have been, almost as a rule ${ }^{2}$, on external funding (i.e., 'soft money'), employed on a short-duration, contract-based, non-tenure track, with the realisation of the hopeful prospect of an eventual promotion to a senior academic position in no way assured (Powell, 2015; Teichler; Cummings, 2015; Waaijer et al., 2017). However, in today's pandemic-riddled realities, the 'rocky road to tenure' (Brechelmacher et al., 2015) is threatening to become even rockier. If in recent years young researchers have had to fight harder than past generations for a constantly decreasing share of the academic pie (Maher; Sureda-Anfres, 2016; Roach; Sauermann, 2017), now that HE institutions worldwide are facing considerable financial stress as part and parcel of the pandemic-generated global economic crisis, things may go from bad to worse.

\subsection{The evolving financial situation in Higher Education systems and its impact on the academic job market}

Indeed, the fall in institutional revenues, entailed mainly by the sharp drop in international student enrolments and the attendant loss in tuition fee and teaching grants, but also by cutbacks in external funding from governmental and private agencies, are already felt (Baker, 2020a; Radecki; Schonfeld, 2020; Ross, 2020; Thatcher et al., 2020). True, as it had been anticipated in the IAUP (International Association of University Presidents) survey of senior leaders of colleges and universities from 92 countries (García; Cherbowski-Lask, 2020), grants directly supporting research have often been more or less spared, remaining to a large extent unaffected by Covid-19 associated developments (Radecki; Schonfeld, 2020; Subbaraman, 2020). Thus, for example, according to Rijs \& Fenter's (2020) findings in a survey targeting researchers, who have published with or acted as reviewers or editors with the OA publisher Frontiers, at least mid-way in the first year of the pandemic the impact on direct allocations for research was not very wide-spread: $33 \%$ of the 25,307 participants reported that there were no changes to the amount of research funding available to them and $6 \%$ even testified to more funding being available, although $25 \%$ did say that with funding having been redirected from their area, less was available. For ECRs, many of whom are employed on 'soft' money, job losses are yet to be realised on a massive scale, especially as institutions have so far cut costs elsewhere (Finkel, 2020; Ross, 2020). Thus, for example, in the US, recipients of grants have even been allowed to charge for costs related to payment of salaries and benefits from all funding sources during periods in which research was not performed due to Covid-19, as long as the grantee's institution allowed such payments (Redden, 2020).

Nevertheless, fears of worse to come loom large with regard to the continued availability of research funding, inclusive of the impact of any changes in this area on the job market, as millions of dollars are being poured into Covid-19 research, arguably leading to what has already been dubbed the Covidisation of research (Pai, 2020). Thus, for example, in the IAUP survey fundraising, cited by $49 \%$ of the 801 participants, was among the top 5 areas where decreases were anticipated, alongside institutional revenue (73\%), student enrollment (59\%), projects with business and industry (56\%), and investment in infrastructure (49\%) (García; Cherbowski-Lask, 2020). Similarly, though Rijs \& Fenter (2020) found relatively little actual reductions in funds for research in their international survey, they did identify widespread concern about the possibility that these are yet to come: $47 \%$ of their respondents opined they will be left with less funding. It is hardly surprising then that the US four major higher education associations, obviously anticipating problems, asked for supplemental funding for research to cover Covid-19 related unanticipated costs, inclusive of costs associated with salaries and benefits for postdoctoral researchers, principal investigators and other research personnel whose salaries are funded by federal grants (Redden, 2020).

The forecasts as to the long-term impact of the pandemic on the academic workforce are none too promising, either, and not surprising, given, for instance, that faculty job openings at US institutions are down $70 \%$ compared with last year (Langin, 2020). The prognostications regarding the UK academic job market, too, indicate impending problems: the po- 
tential impact of the pandemic on HE institutions' enrolments and finances, which was calculated to amount to an average loss of approximately $£ 20$ million in income per higher education institution, could result in approximately 30,000 job losses across the higher education sector (London Economics, 2020). Similarly, in Australia university job losses were projected to come up to 21,000 full time equivalent (FTE) positions over six months, of which an estimated 7,000 could be research-related academic staff (Finkel, 2020). In point of fact, as Thatcher et al. (2020) suggest, extrapolating from the situation in Australia, as employee costs account for the greatest proportion of university spending, the number of FTE positions at universities around the world will decrease as universities look to streamline their cost structures by reducing the number of staff.

\subsection{ECRs' ever-more precarious circumstances in a pandemic-riddled academe}

Plainly then, the unfolding financial situation in HE institutions does not bode well for ECRs: as the most vulnerable (and largest) cohort in the research community, they are particularly prone to hiring freezes and layoffs resulting from the pandemic, indeed, widely assumed to be the ones who will be disproportionally affected by and bear the brunt of the cutbacks already underway and yet to come (Baker, 2020a; Finkel, 2020; Gibson et al., 2020; Maas et al., 2020; Radecki; Schonfeld, 2020; Thatcher et al., 2020). Beyond the direct effects of hiring freezes on junior researchers' future, there are fields in which there is also a more indirect one, as Gibson et al., (2020) point out: if ECRs' ability to hire technical assistance and lab managers is curtailed, it will stymie their ability to generate the preliminary data on which their grant and paper submissions rest.

Not that plans for employment-related cost-saving measures are seen as a favoured solution to the problem: in a Times Higher Education survey of 200 university administrators from 53 nations across 6 continents, who were asked about the effects of Covid-19 on their institution's finances, only a minority said that they were planning redundancies for faculty staff $(12 \%)$, or even the somewhat less draconian steps of furloughs or compulsory paid leave (19\%) or pay cuts (12\%). Still, they were less optimistic with regard to a measure of particular relevance to ECRs: whilst half of them said that they would neither terminate fixed-term contracts nor deny their renewal, nearly one in five said that they would (Bodin, 2020). In fact, ECRs seem to be the low-hanging fruit where cost-saving measures are being considered. Thus, the possible moves cited by the university leaders in the aforementioned IAUP survey were more relevant to junior researchers than to their senior counterparts, as aside from plans to use reserve funds (54\%) and promote early retirements (21\%), they focused on the postponing of hires (54\%), the cancelling of temporary hires $(40 \%)$ and the postponing or cancelling of replacement hires (38\%) (García; Cherbowski-Lask, 2020).

Certainly, ECRs, well-aware of the possibility that they may find themselves at the sharp end of the pandemic-triggered financial problems in the academic world, are very concerned, indeed, about their career prospects. Anecdotal evidence to this effect is pouring in, with novice researchers mincing no words in describing their employment situation as 'dire'... 'grim'... 'double-worse than imagined'... 'scary'... (Langin, 2020; Pain, 2020; Schleunes, 2020; Woolston, 2020a). Beyond the host of random ECR voices lamenting their precarious circumstances amid the pandemic, there is also empirical evidence reflecting their great apprehension and uncertainty around their professional future.

A prime example is a self-selected Nature survey of 7,670 postdoctoral researchers working in academia worldwide, in which almost two-thirds of respondents said that the pandemic negatively affected their career prospects, and another $25 \%$ said that its cumulative effects on their career remained uncertain. Regardless of country of residence, the belief that the pandemic negatively affected career prospects was widespread among them, especially so in South America (70\%), but commonly held in North and Central America (68\%), Australasia (68\%), Asia (61\%), Africa (59\%), China (54\%) and Europe (54\%), too. Their reports as to the prevalent job situation cannot assuage their fears: $13 \%$ of respondents said they had already lost a postdoc job or an offer of one as a result of the pandemic, and $21 \%$ suspected the virus had cancelled a job opportunity but were not sure (Woolston, 2020a).

Bearing out these findings are the results of two surveys of academic journal and book authors from 103 countries, conducted by the academic publisher De Gruyter, the first, conducted early on in the pandemic, with 4,150 participants and the second, conducted towards the end of 2020, with 1,473 participants. The evidence emerging from the study indicates that junior academics are the ones who most fear they will be affected by university budget cuts and will find it hardest to secure new roles, gain promotion and access grant funding. In fact, many early-stage academics have already been found to be stagnating, nervous about the future, passed over for jobs and struggling to obtain funding opportunities (Watchorn; Heckendorf; Smith, 2020).

The available evidence pertaining to individual countries also testifies to the great trepidation among ECRs as to their prospects of landing an academic position or holding on to one. In Australia, for example, a survey among 333 early- and mid-career researchers in science, technology, engineering and mathematics (STEM) indicated that for junior academics uncertainty in their employment situation and perceived loss of career prospects were among the worrying effects of 
Covid-19 restrictions. In particular, they cited end of contract and long-term impact of productivity loss for their careers among the causes for increased anxiety during this time (AAS - EMCR, 2020). Similar evidence emerges from a preliminary, focus-group-series-based study of the short- and long-term impacts of the pandemic on US based early career scholars and doctoral students, which points to their heightened concerns about their employment status and career trajectories. Participants expressed uncertainly or anxiety about their work status, work contractual arrangements and their institution's responses to retention, recruitment, and promotion opportunities. Clearly, the pandemic exacerbated their already precarious situation as ECRs (Levine et al., 2021).

Another country-specific example, which also illustrates the gravity of the problem, emerges from the findings of a survey with more than 5900 UK-based doctoral researchers and research staff participants. Undertaken in the pandemic's first wave in the spring of 2020, it already indicated that half of them were very stressed about their work, two thirds said they were very worried about their future plans and $70 \%$ testified to apprehensions about their finances. With good reason, too: around a third of respondents reported a change in their employment options outside of academia since the lockdown, with around four-fifths of these expecting an impact on their finances for the next academic year. Also, $40 \%$ of the research staff among those surveyed were on contracts ending during 2020, but only $10 \%$ of them had their funding extended to offset the effects of the pandemic (Baker, 2020b; Byrom, 2020; SMaRteN; Vitae, 2020). Further exacerbating the problem, according to Baker (2020a), novice academics in the UK are disadvantaged by the country's furlough scheme -where the government is covering the pay of many employees unable to work during lockdown-which has not been used for many postdoctoral academics on grant-funded contracts and fellowships.

The writing on the wall is, thus, there for all to see: with the HE sector facing pandemic-associated financial pressures, held to be increasingly likely to result in both a forthcoming dearth of job openings and more and more job losses, ECRs certainly need to prepare themselves for troubling times ahead. However, the challenges they need to tackle, if they are intent on making it in academe, do not end with employment-related problems.

\section{Undertaking research during the pandemic and its challenges for ECRs}

\subsection{Background and context: ECRs' commitment to their chosen vocation}

Not only do young scholars' employment prospects look gloomy amidst the pandemic-unleashed plights, but so does their scholarly future, too, for building up a good research record, the undisputed key to becoming a full-fledged member of the scientific community, also seems to be much more fraught with problems. Not that it has been an easily accomplished achievement even in pre-pandemic times, given the extent to which peer reviewed publications in top ranked journals or with reputable publishing houses, and the recognition that flows therefrom, are considered the mainstay of scholarly success (Blankstein; Wolff-Eisenberg, 2019; Borrego; Anglada, 2016; Cronin, 2001; Harley et al., 2010; Herman; Nicholas, 2019; Mulligan; Hall; Raphael, 2013; Nicholas et al., 2015). In fact, for quite some time now, ECRs, as hopeful entrants to academe, have been obliged to prove that they are worthy candidates for a scholarly career by publishing more, at a younger age and in more prestigious journals than their seniors ever needed to (Hangel; Schmidt-Pfister, 2017; Müller, 2014a). Not only has this strong focus on fast and major research achievement created for junior researchers a climate of constant rush and fear of lagging behind (Müller, 2014a; Müller, 2014b), but it also has had them ever-more tied down by the journal-centred publishing dictates of the scholarly system (Nicholas et al., 2019; Nicholas et al., 2020a; Nicholas et al., 2020b; Schoen et al., 2014).

Nevertheless, highly appreciative of the intellectual challenge, independence and creativity a scholarly career is seen to offer, newcomers to academe are deeply committed to their chosen vocation (Friesenhahn; Beaudry, 2014; Fransman, 2014; Sauermann; Roach, 2012). The aforementioned Nature survey of postdoctoral researchers leaves no doubt that even in the face of a pandemic that puts them in a more precarious position than ever, they hold on to their aspirations: six out of ten say that they are satisfied with their positions, and about two-thirds of respondents -and $80 \%$ of those who currently work in North America or Europe- still see academia as their preferred career destination (Woolston, 2020b). Inevitably then, intent as they are upon doing whatever it takes to attain their goal of becoming a scholar and cognisant of the strong focus on research achievements in academic reward systems, ECRs place much effort on the research-related aspects of their scholarly work (Nicholas et al., 2017; Nicholas et al., 2019; Nicholas et al., 2020a; Nicholas et al., 2020b; Nicholas et al., 2020c).

\subsection{The pandemic-generated disruptions to the scholarly undertaking: lockdowns and social distancing}

Unfortunately, the pandemic puts in quandary their ability to reap the benefits of their commitment to research and willingness to work hard. Indeed, with all that the virus has been impacting all scholars, it is ECRs who are in all likelihood to pay -if not already paying - the highest price of the pandemic's putting the brakes on research endeavours. After all, they 
are the ones whose scholarly fate is on the line, who have to prove themselves in order to gain entrance to academia. This, as ever, is dependent on their accumulating demonstrable research achievements in as short time as possible, but in these pandemic times also on their ability to hurdle unprecedented disruptions to the scholarly undertaking. Hardly easy, for ECRs are no exception when it comes to the effects of the pandemic on the feasibility of doing research and building a successful track record; rather the contrary, despite efforts to counter-balance the problem through tenure clock extensions put in place at many universities.

Not that more senior scholars have it easy: for example, in a survey that focused on open data, but looked at research practices in the wake of Covid-19, too, over a third of the 3,436 respondents reported that their work had been extremely or very much impacted by the pandemic and another third said it prevented them from doing at least some of their work (Baynes; Hahnel, 2020). Still, ECRs' circumstances seem to be even more challenging. Indeed, the data in the Nature survey of the impact of the pandemic on postdoctoral researchers leaves a strong impression that ECRs have been hit hard: 8 out of 10 postdocs testified to having trouble performing experiments or collecting data and nearly 6 out of 10 postdocs said they had difficulties discussing ideas with their lab head and colleagues (Woolston, 2020a). By the same token, in a survey among 881 life scientists in Germany, Spain, UK, Italy, France, Canada, Turkey, and the US, 72\% of which were trainees (referred to elsewhere in the article as junior scientists), not only was work reported to have been lost during the pandemic, but levels of self-perceived productivity were said to have dropped, too (Korbel; Stegle, 2020).

ECRs' vulnerability in these trying times is, perhaps, best exemplified by what is arguably the most pervasive disruption of them all, the ramping down, if not total shutdown of non-Covid-19 related or non-essential on-site research activities, as part and parcel of HE institutions, worldwide, complying with the call for preserving the safety of their communities and adhering to public health guidance (Wigginton et al., 2020). Indeed, evidence emerging from country-specific surveys points to the dire effects of lockdowns, social distancing and travel bans on junior scholars' research activities. Thus, in the UK, more than three-quarters of the respondents in the above-cited SMaRteN and Vitae survey of over 5900 ECRs reported that they were experiencing a negative impact of the lockdown on their ability to collect data, discuss ideas and findings with colleagues and disseminate research findings. More than half also identified a negative impact on data analysis, writing, and working on grant or fellowship applications (Baker, 2020b; Byrom, 2020; SMaRteN; Vitae, 2020). By the same token, in the AAS-EMCR (2020) survey among 333 Australian early and mid-career researchers, 83\% felt that these changes in their workplace made them less productive, with $57 \%$ specifically of ECR participants reporting that their ability to undertake research was hindered, bringing about a loss of productivity because of the inability to collect data and lack of international opportunities.

Certainly, the lockdowns, bringing about as they do the closing down of the physical facilities and/or the ban on travel to or from research sites, have been acutely felt in laboratory- clinic- or field-work based disciplinary areas, where research work, unless directly concerned with the virus, was forced to ground to a halt, or at best, to slow down. In result, work already done and critical data already gathered were lost and productivity was held up (Baynes; Hahnel, 2020; Levine et al., 2021; Radecki; Schonfeld, 2020; Watchorn et al., 2020), with 'bench sciences' -fields that rely on physical laboratories and time sensitive experiments- experiencing the largest declines in research time, in the range of 30-40\% below pre-pandemic levels (Myers et al., 2020). Still, the effects of the lockdowns have been felt in other disciplinary areas, too, with the lowest level of impact reported in the humanities and the social sciences (Baynes; Hahnel, 2020). Nevertheless, in the De Gruyter surveys, $55 \%$ of humanities scholars were found to be limited in their work because they were unable to access essential non-digitised resource libraries, older books, archives or physical collections (Smith; Watchorn, 2020; Watchorn et al., 2020).

It is not very surprising then that in the case of ECRs, too, the disciplinary differences identified in their approximation of the damage to their career prospects are traceable to the extent of disruptions to their research: slightly less than half of researchers in the desk-research centred knowledge areas of computer science and mathematics thought that their career prospects had suffered, compared to $68 \%$ and $60 \%$ of researchers, respectively, in the experimental-research centred areas of chemistry and biomedicine and with $67 \%$ in the field-research centred areas of ecology and evolution (Woolston, 2020a). Indeed, as anecdotal evidence cited by Forrester (2020) indicates, the pandemic has presented new and unexpected challenges for those who planned or were already on field excursions, with the effects of the restrictions felt especially profoundly by ECRs. Forced to redefine what is feasible given tightened budgets and time frames, they were faced with unforeseen difficulties, even when travel became feasible again, such as the need to acquire protective equipment not originally budgeted for or the need to cut down on the number of people who travelled, which increased the workload for those who could go. 


\subsection{The pandemic-generated disruptions to the scholarly undertaking: restrictions on travel}

The pandemic-enforced restrictions on travel, overturning as they do researchers' traditional ways of collaborating, cooperating and networking, hit a particularly sensitive nerve for many researchers, indeed, has even been described as "starving researchers of the lifeblood of their profession" (Watchorn et al., 2020, p. 9). Inevitably so, perhaps, for, as it has long been established, the cultivation of science is a highly communal undertaking that hinges on interactive communication among similarly interested individuals (Becher; Trowler, 2001; Merton, 1973), so much so, that the last few decades have even been seeing a veritable paradigm shift in scientific research from a singular enterprise into a social endeavour (Herman; Nicholas, 2019). With little, if any travel possible, social media platforms and video conferencing have been taking the place of face-to-face meetings in scholarly circles, too. Still, the developments in this area have been accorded a more mixed reception among scholars than their well-known predisposition towards established ways and means of working might have predicted.

Thus, some academics enthusiastically approve of the shift to online, which enables them to connect with colleagues locally and globally via the use of a wide range of video conferencing (VC) systems, teleconferencing platforms, or collaboration tools such as Slack, whilst saving valuable time spent on travel and administration (Korbel; Stegle, 2020; Levine et al., 2011; Olena, 2020). Others see things quite differently, perceiving this state of affairs as growingly problematic, indeed, as signaling the possibility of more severe impediments to researchers' ability to collaborate, find co-authors and network yet to come (Levine et al., 2011). Indeed, while $29 \%$ of the 4,150 participants in the first De Gruyter survey in May reported the switch to online conferences a problem, $43 \%$ of the 1,473 participants did so in the October survey; while $29 \%$ saw lack of collaboration opportunities as one of biggest barriers to research productivity in May, their percentage grew to $37 \%$ in October (Watchorn et al., 2020).

However, perhaps, a proof that this pessimistic appreciation of the feasibility of travel-bans restricted cooperation and collaboration is not wholly divorced from reality is that even the unprecedented rate of international Covid-focused research collaboration (Korbel; Stegle, 2020; Radecki; Schonfeld, 2020) fell in terms of participating nations and team size in late spring and through the summer and early autumn. True, the phenomenon is traced back in part to political obstacles, but travel bans and their role in curtailing the formation of research collaborations are seen as an even more central factor (Baker, 2020c; Cai; Fry; Wagner, 2020; Fry et al., 2020).

When it comes to the effects of the pandemic-imposed onus to switch to online communication in the scholarly community, ECRs -again- are the ones disproportionately impacted, although in this case perhaps not invariably adversely. Thus, for example, virtual conferences can be a bonus for ECRs, whose funds may be too limited to allow for attending face to face events, especially when these are located outside their own countries. Indeed, proponents of online conferences point to increased accessibility, alongside reduced carbon emissions, as they argue for making the pandemic-induced changes to meetings permanent (Olena, 2020). In fact, going virtual has been suggested as a prime way for mitigating the impact of conference and travel cancellations on researchers' futures (Weissgerber et al., 2020).

Nevertheless, it is not the cure-all it may seem, for novice researchers, who are still struggling to form the vital connections they need with other scholars in their academic and disciplinary communities, attend conferences with the express purpose of socializing, networking and gaining the attention, recognition and feedback of their colleagues, even finding out about open positions (Kwon, 2020; Weissgerber et al., 2020). Online conferences are hardly the best way to go about accomplishing any of these goals, for, as one junior researcher put it, "it is not ideal to network while staring at screens" (Arnold; Woolston, 2020). The diminished opportunities for making connections, as Watchorn et al. (2020) suggest, may have far-reaching repercussions for novice researchers: if they cannot find the collaborators they need to get their first step on the career ladder, their entire publishing output will be impacted.

\subsection{A silver lining to the Covid-19 clouds?}

However, if there is a silver lining to the unwelcome effects that the pandemic has on scholars' research productivity, it is that the down-time has provided some of them -senior and junior scholars alike- additional time to focus on data analysis, writing, and working on grant or fellowship applications. Thus, in above-cited focus-group-series study of US early career scholars and doctoral students, the participants reported that they had worked intensively to sustain or even increase their research productivity so as to take advantage of the opportunity to get more done when institutions' shifting to remote work made it more possible (Levine et al., 2021).

Indeed, three-quarters of the more than 25,000 participants in the aforementioned Frontiers survey, too, reported that they were writing papers for publication -a task which can more readily be performed remotely (Rijs; Fenter, 2020)-. Korbel \& Oliver (2020), too, find that almost half of their respondents had more time to devote to data analysis (43\%) 
and manuscript or thesis writing (45\%), although only $11 \%$ mentioned in this context the developing of grant applications. Woolston (2020a), too, says that for $43 \%$ of their postdoc respondents a small consolation in the pandemic was that writing had become easier. Still, more than one-quarter (26\%) of their respondents did say that the pandemic had the opposite effect, as did the participants in the SMaRteN \& Vitae survey of novice researchers, more than half of whom reported that the lockdowns had a negative impact of on their data analysis, writing papers and making funding applications (Baker, 2020b; Byrom, 2020; SMaRteN; Vitae, 2020).
With little, if any travel possible, social media platforms and video conferencing have been taking the place of face-to-face meetings in scholarly circles, too. Still, the developments in this area have been accorded a more mixed reception among scholars than their well-known predisposition towards established ways and means of working might have predicted

There can be little doubt then that the pandemic has already resulted in significant disruptions in the pace of research and the foci of its component activities, among which communication and cooperation figure highest. Plainly, this is a state of affairs that renders ECRs particularly susceptible to harm, for they need to produce concrete evidence to prove their research capabilities if they are to gain entrance to the scholarly community. However, as the just cited mixed reports on researchers' experiences regarding the writing of papers during lockdowns demonstrate, reflecting as they do variations that do not invariably seem to be directly attributable to career stage and/or the nature of work common to a field, the individual-level differences in the effects of the pandemic may be due to an additional factor, too: the availability of time as it is determined by a researcher's unique personal circumstances.

\section{ECRs' work-life under the virus-dictated rules of the 'new scholarly normal'}

\subsection{Researchers' personal circumstances as determinants of their scholarly performance during the pan- demic}

Research, as every scholar will agree, is a time-intensive undertaking, which, although often prioritized, still has to be undertaken alongside a considerable number of other work- and life-tasks. However, if the resulting pressures have long rendered time a rare commodity for the researcher, it must be tenfold with Covid-19 wreaking havoc on customary practices. True, the above-mentioned Frontiers survey found that in the first six months of the pandemic researchers' day to day work had not been significantly affected, with many able to continue their professional role throughout: around four in five of their participants reported either that their work was unaffected, or that they have managed to adapt working practices to perform their role and maintain a level of continuity (Rijs; Fenter, 2020). However, there is more and more evidence indicating that things are less rosy than it could have been hoped for on the basis of these findings, from a host of first-hand testimonies (see, for example, Cheng; Song, 2020 or the series Introductions to the community: Early-career researchers in the time of Covid-19), to an increasing number of studies providing empirical data.

A case in point is a survey with 4535 US- and Europe-based scientist participants, conducted early-on in the pandemic, which, setting out to solicit information about the time scientists devote to research, already found an overall decline in their total working hours. Thus, the average dropped from 61 hours per week pre-pandemic to 54 hours at the time of the survey, with research faring the worst among the different types of work-tasks: whereas total working hours decreased by $11 \%$ on average, time devoted to research declined by $24 \%$. In fact, in terms of the share of time allocated across the tasks, research is the only category that saw an overall decline, although not all researchers reduced the time they devoted to research during the pandemic: $21 \%$ reported spending more time on research and $9 \%$ reported no change (Myers et al., 2020).

As a matter of fact, Myers et al.'s (2020) findings are not all that surprising, for in the realities of today's 'new scholarly normal' researchers face unprecedented challenges in attempting to maintain a reasonable work-life balance. Most notably perhaps, it is the excess of work caused by teaching and supervising students online, which is taking up more time than expected, coupled with the onus to work from home, which entails the necessity to juggle work and domestic activities, that create greater time pressures (Minello; Martucci; Manzo, 2020; Watchorn et al., 2020). However, some researchers are better placed to emerge relatively unscathed from the struggle than others: as Maas et al. (2020) suggest, the pandemic-induced concurrent increase in responsibilities both on the work and the home fronts particularly risks scientists from vulnerable groups becoming severely overburdened.

Indeed, as Watchorn et al. (2020) find, whilst late-career researchers, which they define as academics with more than 16 years of post-PhD experience, have remained relatively protected from the worst disruption caused by the pandemic, their younger colleagues have not been as fortunate. Thus, compared to less senior academics, late-career researchers were more likely to be able to dedicate the same amount of time to their research as they did pre-pandemic, which is arguably why for $67 \%$
If there is a silver lining to the unwelcome effects that the pandemic has on scholars' research productivity, it is that the down-time has provided some of them -senior and junior scholars alikeadditional time to focus on data analysis, writing, and working on grant or fellowship applications 
of them the pandemic resulted in 'minimal impact' on their ability to get their work published, for $40 \%$ workloads remained unchanged since the outbreak began and for $26 \%$ research plans even remained entirely unaffected -they were able to continue as normal-. Not so, however, where mid-career researchers, defined as having six to 15 years of academic experience post-PhD, or early-career researchers, defined as academics with one to five years' experience post-PhD, were concerned. Scholars at the mid-point in their careers -and women in particular- were found to be especially squeezed in terms of their time, focus and energy, with $57 \%$ of them saying that they had spent less time conducting critical primary research than they would have expected in a typical year, and with nearly three-quarters experiencing obstacles that were directly limiting their research and writing productivity.
In the realities of today's 'new scholarly normal' researchers face unprecedented challenges in attempting to maintain a reasonable work-life balance. Most notably perhaps, it is the excess of work caused by teaching and supervising students online, which is taking up more time than expected, coupled with the onus to work from home, which entails the necessity to juggle work and domestic activities, that create greater time pressures

Moreover, the pressures they battled had a knock-on impact for their ECR colleagues, who were failing to receive the formal and informal support they need to advance their careers. Lending further support to Watchorn et al.'s (2020) portrayal of the gaps in support resulting from domestic responsibilities, in the Nature survey of postdocs only around half of them said that they felt supported by their principal investigator (PI) during the pandemic and around one quarter even reported a lack of guidance from their PI around their ability to work because of the pandemic (Woolston, 2020a). By the same token, in Levine et al.'s (2021) aforementioned focus groups study the participants said that they would have liked their institutions to provide more research support and more senior-level guidance. Still, they were cognizant of the multiple parallel crises that their institutions faced, a sentiment echoed in the SMaRteN \& Vitae survey, too, in which many of their junior researcher participants did recognise the difficulties experienced by their supervisors. Thus, two-thirds of them reported that their supervisor or line manager had done all they could or should do to provide support at this time, and around half of them said that their supervisor or line manager had made arrangements to support them to stay in touch with peers and colleagues (Byrom, 2020).

\subsection{The greater burden on scholars with domestic and caring responsibilities: the case of ECRs}

Plainly though, when it comes to time allocated to research, scholars who have domestic and caring responsibilities have been found to bear the brunt of the additional burdens of working from home, investing as they did substantial time and energy into supporting their families and helping them deal with the disruptions and traumas caused by Covid-19 (Levine et al., 2021). Thus, for example, of the participants in the SMaRteN \& Vitae survey who had caring duties, about 90 per cent said their responsibilities had increased since the lockdown, with almost nine out of 10 of this group saying this had led to a negative impact on their ability to keep up with work (Baker, 2020b). Watchorn et al. (2020) also report that $51 \%$ of the mid-career researcher participants in their survey said that they were 'severely limited' from researching and writing because of caring for young children -compared with just $16 \%$ of late-career scholars-. Similarly, those with caring responsibilities in the survey of Australian early and mid-career researchers reported that the increase in these responsibilities during the pandemic impacted their ability to work, with $50 \%$ of male and $62 \%$ of female researchers saying so (AAS - EMCR, 2020).

Women researchers are clearly in the eye of the storm, which is perhaps inevitable, as women traditionally shoulder more domestic duties than men whilst also more often responsible for service and student mentorship than their male colleagues in academia (Maas et al., 2020; Minello, 2020). Thus, as Myers et al. (2020) find, scientists with at least one child 5 years old or younger experienced a 17\% larger decline in research time, and having multiple dependents was associated with a further $3 \%$ reduction in time spent on research, so that the gender discrepancy arising from these results -female scientists reported a $5 \%$ larger decline in research time- can be attributed to their being more likely to have young children as dependents. The results of a global survey, based on responses from 19,905 academics across various disciplines lend further support to Myers et al.'s findings: whilst there were substantial increases in child care and housework burdens during the pandemic for both men and women, female researchers, and particularly those with children, experienced a disproportionate reduction in time dedicated to research. Indeed, the effects of having a child was found to be doubled for female academics, as overall women with children lost about an hour of research time per day more than childless men did (Deryugina; Shurchkov; Stearns, 2021). In fact, as Watchorn et al. (2020) conclude from their data, whilst both male and female researchers are busy with online teaching -and clearly, some men face domestic disruptions too-female academics are far more affected: $48 \%$ of female scholars said they were having difficulty staying engaged and productive compared to $28 \%$ of men. Moreover, as a comparison of the results of their May and October surveys indicate, the pressures on women are increasing while the pressures on men are declining. 
No surprise, then, in what seems to be the inescapable result of these developments, that there have been pandemic-associated significant drops in scholarly production and publishing by female researchers (for extensive reviews of the evidence see Oleschuk, 2020; Peters, 2020; Radecki; Schonfeld, 2020; Viglione, 2020). Indeed, in a qualitative interview study of 12 Italian and 25 US women academics, all mothers of young children who experienced an increase in the time dedicated to care, Minello et al. (2020) identified a shift of focus in their activities, which offers a more nuanced explanation to the phenomenon: they invested much of their attention in teaching duties, which resulted in their having to postpone or discard their research.
There have been pandemic-associated significant drops in scholarly production and publishing by female researchers... However, it is the ECRs among women researchers whose research productivity has been shown to be even more disproportionately affected by the pandemic... if pre-pandemic early career women researchers faced significant barriers to academic success, it is all the more so now

However, it is the ECRs among women researchers whose research productivity has been shown to be even more disproportionately affected by the pandemic, which, in light of what we have just seen, is unsurprising: after all, they are at an age which increases the likelihood of their being mothers of small children, or, for that matter, daughters of aging parents. Indeed, as Cardel et al. (2020) find from the literature, if pre-pandemic early career women researchers faced significant barriers to academic success, it is all the more so now: decreased productivity among women was already evident early on in the pandemic, with overall manuscript submissions on a downward trend among women compared with men and women making up only $12 \%$ of the authors of Covid-19-related research.

Vincent-Lamarre, Sugimoto \& Larivière's (2020a, 2020b) research lends further support to these findings: their analysis of 307,459 submissions by 1.3 million authors to 11 pre-print repositories and three platforms for registered reports, using authorship position as a proxy for seniority in science, suggests that early career female submissions have experienced a larger reduction, with the largest drop in Covid-related research, which, obviously, directly represents research activity during the pandemic. Similarly, Squazzoni et al., (2020), having looked at submitted manuscripts for all Elsevier journals between February and May 2018-2020, found that the women among 6 million authors submitted proportionally fewer manuscripts than the men during the Covid-19 lockdown months, with the deficit most pronounced among women at intermediate or advanced stages of their career compared to PhD students and researchers without a PhD, who were in all likelihood younger and, therefore, less burdened with intense family duties.

Apparently then, the work-life of ECRs has indeed been greatly affected by the virus-dictated rules of the 'new normal' in the research undertaking. Being at an age when they are more likely to have children (or aging parents) as dependents, they, and especially the women among them, often find themselves too overburdened with caring responsibilities to devote the time they need to advance their budding careers. The detrimental effects of the delays thus incurred to their track record might turn out to be harmful, if not irrevocably damaging to their scholarly progress.

\section{Conclusions}

If there is a main theme to emerge from this literature-based exploration of how ECRs fare in a pandemic-challenged scholarly world, it is the one encapsulated in Vincent-Lamarre et al.'s (2020a; 2020b) observation: we are all in the same storm, but not in the same boat. Indeed, with all that the pandemic has not left -could not possibly leave- any scholar untouched, junior researchers are faced with added and more taxing challenges. The host of scientific studies, expert prognostications and personal accounts reviewed here leave little room for doubt: junior researchers are already disproportionally affected by and bear the burden of the ongoing pandemic-incurred hardships and they are likely to remain similarly impacted when more trials, still unfolding and yet to come, materialise. The evidence is quite conclusive, whether it concerns the impacts of the financial pressures felt in the HE system on their careers, the disruptions in the pace/focus of their research undertakings or the virus-dictated circumstances of their work-life under the rules of the 'new scholarly normal'.

This is hardly an unexpected turn of events: as the most vulnerable cohort in the academic workforce, ECRs are particularly prone to the hiring freezes, layoffs and dearth of job openings resulting from the pandemic; as aspiring entrants to academe, who need to demonstrate research capabilities, ECRs are particularly prone to the detrimental effects of the pandemic's putting the brakes on productivity, collaboration and cooperation; as young people with a concurrent excess of responsibilities, brought about by the pandemic both on the work and the home fronts, ECRs, and especiaIly the women and even more so the mothers of young children among them, are particularly prone to an inability to achieve a reasonable work-life balance. This state of affairs is likely to trap ECRs in a vicious circle, even if they already have or manage to gain a position in a HE institution: if their opportunities to conduct research are compromised during Covid-19, they cannot build a successful track record. Without a successful track record, they cannot receive external funding. Without funding, their productivity is further limited, which, coupled with the pandemic-associated lowering of productivity, causes their track record to deteriorate, resulting in even less opportunities for conducting research and getting grants. Undeniably, the disruptions in their careers during Covid-19 will have compounding effects for their professional future. 
However, beyond the individual-level barriers to success brought on by the pandemic, there are bound to be far-fetching long-term effects on the entire research enterprise, too, unless swift preventative and mitigating actions are taken. ECRs are the veritable 'workhorses' of research, who spend twice as much time on research as their older counterparts (Baker, 2020a). Not only are they dedicated researchers and prolific authors, but they have also been shown to be heavily involved in the various aspects of research work, from conducting field work, performing experiments and analysing data to reviewing the literature (Jamali et al., 2020; Nicholas et al., 2017). Indeed, as Simon Marginson, an Oxford University professor (cited in Baker, 2020a) argues, given the huge proportion of the scholarly work that ECRs take upon themselves, if they are left behind and the oft-heard threat of their becoming 'the lost generation of researchers' becomes reality, both research quantity and its quality could be affected. This when young scientists, widely recognized as particularly creative and energetic researchers, constitute a vast pool of global talent that can play a central role in knowledge economies, indeed, can provide the intellectual capital needed to grow a strong national research and innovation system (Friesenhahn; Beaudry, 2014).

True, some impacts of the pandemic may turn out to be a blessing in disguise for the scholarly enterprise as we know it. As Subbaraman (2020) suggests, the pandemic could highlight the importance of science and collaboration and spur long-term support, especially for basic research, much as the Second World War did. It is just conceivable then that in a world where the scholarly endeavour assumes an ever-more significant role, today's millennial ECRs, with the open-mindedness and resilience so characteristic of their generation (Duffy; Shrimpton; Clemence, 2017; FEPS, 2018; Pew Research Center, 2010a; 2010b), will change the system from above, on the policy-making level, but also from within. If so, then their scholarly views, more revolutionary than those of their senior counterparts (Nicholas et al., 2019; Nicholas et al., 2020a; 2020c), may finally come into fruition: for example, ECRs may see fit to make much more headway than before in the adoption of Open Science practices, with high levels of transparency, accessibility and collaboration, for these would enable a more successful individual-level building of reputation, whilst also affording the attainment of scientific advances in more effective and efficient ways. We have found little in the way of research on this possibility of ECRs' using any opportunities that the pandemic might have raised to bring about fundamental changes in the scholarly communications system, but we shall certainly look into the matter in our longitudinal international study, currently underway, and return to the literature again when we report on our findings.

Finally, we are not in a position yet -just three months into our two-year project- to suggest how the challenges outlined in this paper may be prevented or at least mitigated. However, what already seems to be the inevitable conclusion emerging from this literature-based analysis of the impacts on ECRs of pandemic-incurred developments is that much needs to be done on the institutional and governmental policy-making level to prevent the grim scenario that Cardel $e t$ al. (2020) talk about and warn against: a secondary epidemic of lost early career scientists.

\section{Notes}

1. The term ECR, as used in this article, follows Hollywood et al.'s (2020) conceptualisation of ECAs (Early Career Academics), which recognises the different roles they fulfil and the diversity in the types of their employment, but nevertheless has at its heart the common denominators of their standing in the scholarly world: they are all early in their career in an academic environment and holding individual career aspirations whilst simultaneously managing performance against targets.

2. Although temporary models of employment have increasingly been characterising academia for quite some time now, there are variations in type and prevalence among different countries; for details see: Castellacci \& Viñas-Bardolet, 2020, Appendix 1; Crick, Larson \& Seipel, 2020; Frølich et al., 2018; Waaijer et al., 2017.

\section{References}

AAS; EMCR-Early; Mid-Career Researcher Forum (2020). Impacts of Covid-19 for EMCRS. National survey report, August 12. Australian Academy of Science.

https://www.science.org.au/files/userfiles/support/documents/covid19-emcr-impact-report.pdf

Anderson, Janna Q.; Rainie, Lee (2010b). Millennials will make online sharing in networks a lifelong habit. Pew Research Center. https://www.pewinternet.org/2010/07/09/millennials-will-make-online-sharing-in-networks-a-lifelong-habit

Arnold, Carrie; Woolston, Chris (2020). “Uncertainty plagues junior researchers from underprivileged backgrounds amid pandemic". Nature, n. 588, pp. 355-357.

https://doi.org/10.1038/d41586-020-03465-0

Baker, Simon (2020a). "HE financial crisis risks 'lost generation of researchers'”. Times higher education, June 11. https://www.timeshighereducation.com/news/he-financial-crisis-risks-lost-generation-researchers

Baker, Simon (2020b). "Most early career academics face funding cliff edge, survey suggests". Times higher education, May 18. https://www.timeshighereducation.com/news/most-early-career-academics-face-funding-cliff-edge-survey-suggests 
Baker, Simon (2020c). "Question over political control as Covid collaboration falls back". Times higher education, December 4.

https://www.timeshighereducation.com/news/question-over-political-control-covid-collaboration-falls-back

Baynes, Grace; Hahnel, Mark (2020). "Research practices in the wake of Covid-19". In: Digital science report. The state of open data 2020. London: Digital Science; Figshare, pp. 22-25. ISBN: 9781999317751 https://doi.org/10.6084/m9.figshare.13227875.v2

Becher, Tony; Trowler, Paul R. (2001). Academic tribes and territories: Intellectual enquiry and the culture of disciplines, $2^{\text {nd }}$ ed. Buckingham, UK: The Society for Research into Higher Education \& Open University Press. ISBN: 0335206271

Bennion, Alice; Locke, William (2010). "The early career paths and employment conditions of the academic profession in 17 countries". European review, n. 18, S1, S7-S33.

https://doi.org/10.1017/S1062798709990299

Blankstein, Melissa; Wolff-Eisenberg, Christine (2019). Ithaka S+R US faculty survey 2018. New York, NY: Ithaka S+R. https://sr.ithaka.org/wp-content/uploads/2019/03/SR-Report-US-Faculty-Survey-2018-04122019.pdf

Bodin, Madeline (2020). "University redundancies, furloughs and pay cuts might loom amid the pandemic, survey finds". Nature. Career news, 30 July. https://doi.org/10.1038/d41586-020-02265-w

Borrego, Ángel; Anglada, Lluís (2016). "Faculty information behaviour in the electronic environment: Attitudes towards searching, publishing and libraries". New library world, v. 117, n. 3/4, pp. 173-185.

https://doi.org/10.1108/NLW-11-2015-0089

Brechelmacher, Angelika; Park, Elke; Ates, Gulay; Campbell, David F. J. (2015). "The rocky road to tenure-career paths in academia". In: Fumasoli, Tatiana; Goastellec, Gaële; Kehm, Barbara M. (eds.). Academic work and careers in Europe: Trends, challenges, perspectives. Cham: Springer. https://doi.org/10.1007/978-3-319-10720-2_2

Byrom, Nicola (2020). "Covid-19 and the research community: The challenges of lockdown for early-career researchers". eLife, n. 9, e59634.

https://doi.org/10.7554/eLife.59634

Cai, Xiaojing; Fry, Caroline V.; Wagner, Caroline (2020). "International collaboration during the Covid-19 crisis: Autumn 2020 developments". Preprint.

https://doi.org/10.2139/ssrn.3729672

Cardel, Michelle I.; Dean, Natalie; Montoya-Williams, Diana (2020). "Preventing a secondary epidemic of lost early career scientists. Effects of Covid-19 pandemic on women with children". Annals of the American Thoracic Society, v. 17, n. 11 , pp. $1366-1370$. https://doi.org/10.1513/AnnalsATS.202006-589IP

Castellacci, Fulvio; Viñas-Bardolet, Clara (2020). "Permanent contracts and job satisfaction in academia: Evidence from European countries". Studies in higher education, v. 1, n. 15. https://doi.org/10.1080/03075079.2019.1711041

Cheng, Cen; Shufei, Song (2020). "How early-career researchers are navigating the Covid-19 pandemic". Molecular plant, v. 13, n. 9, pp. 1229-1230. https://doi.org/10.1016/j.molp.2020.07.018

Crick, Kent A.; Larson, Lisa M.; Seipel, Matthew T. (2020). "Non-tenure track faculty satisfaction: A self-determination model". Journal of career assessment, v. 28, n. 3, pp. 425-445. https://doi.org/10.1177/1069072719870681

Cronin, Blaise (2001). "Hyperauthorship: A postmodern perversion or evidence of a structural shift in scholarly communication practices?". Journal of the American Society for Information Science and Technology, v. 52, n. 7, pp. 558-569. https://doi.org/10.1002/asi.1097

Deryugina, Tatyana; Shurchkov, Olga; Stearns, Jenna E. (2021). Covid-19 disruptions disproportionately affect female academics. National Bureau of Economic Research (NBER) Working paper n. 28360. https://doi.org/10.3386/w28360

Duffy, Bobby; Shrimpton, Hannah; Clemence, Michael (2017) Millennial myths and realities. London: Ipsos Mori. https://www.ipsos.com/ipsos-mori/en-uk/millennial-myths-and-realities

FEPS; ThinkYoung (2018) The millennial dialogue: Engaging and creating a better understanding of the priorities and values of millennials. Foundation for European Progressive Studies; ThinkYoung.

https://www.millennialdialogue.com/\#download 
Finkel, Alan (2020). Impact of the pandemic on Australia's research workforce. Research report, 6 May. Australian Academy of Science. Rapid Research Information Forum.

https://www.science.org.au/sites/default/files/rrif-covid19-research-workforce.pdf

Forrester, Nikki (2020). "How to manage when your fieldwork is cancelled". Nature. Career news, 27 November. https://doi.org/10.1038/d41586-020-03368-0

Fransman, Jude (2014). "Becoming academic in the digital age: Negotiations of identity in the daily practices of early career researchers". In: The SRHE annual conference 2013.

https://www.srhe.ac.uk/downloads/FRANSMAN_Final_Report.pdf

Friesenhahn, Irene; Beaudry, Catherine (2014). The global state of young scientists. Project report and recommendations. Berlin: Akademie Verlag. ISBN: 9783939818441

https://globalyoungacademy.net/wp-content/uploads/2015/06/GYA_GloSYS-report_webversion.pdf

Frølich, Nicolin; Wendt, Kaja-Kathrine; Reymert, Ingvilt S.; Tellmann, Silje-Maria; Elken, Mari; Kyvik, Svein; Vabø, Agnete; Larsen, Even-Hellan (2018). Academic career structures in Europe: Perspectives from Norway, Denmark, Sweden, Finland, the Netherlands, Austria and the UK. Oslo: Nordic Institute for Studies in Innovation, Research and Education NIFU. ISBN: 9788232703180

Fry, Caroline V.; Cai, Xiaojing; Zhang, Yi; Wagner, Caroline S. (2020). "Consolidation in a crisis: Patterns of international collaboration in early Covid-19 research". PLoS one, v. 15, n. 7, e0236307.

https://doi.org/10.1371/journal.pone.0236307

Gibson, Erin M.; Bennett, F. Chris; Gillespie, Shawn M.; Güler, Ali-Deniz; Gutmann, David H.; Halpern, Casey H.; Kucenas, Sara C.; Kushida, Clete A.; Lemieux, Mackenzie; Liddelow, Shane; Macauley, Shannon L.; Li, Qingyu; Quinn, Matthew A.; Roberts, Laura-Weiss; Saligrama, Naresha; Taylor, Kathryn R.; Venkatesh, Humsa S.; Yalçın, Belgin; Zuchero, J. Bradley (2020). "How support of early career researchers can reset science in the post-Covid19 world". Cell, v. 181, n. 7, pp. 1445-1449. https://doi.org/10.1016/j.cell.2020.05.045

Hangel, Nora; Schmidt-Pfister, Diana (2017). "Why do you publish? On the tensions between generating scientific knowledge and publication pressure". Aslib journal of information management, v. 69, n. 5, pp. 529-544.

https://doi.org/10.1108/AJIM-01-2017-0019

Harley, Diane; Acord, Sophia-Krzys; Earl-Novell, Sarah; Lawrence, Shannon; King, C. Judson (2010). Assessing the future landscape of scholarly communication: An exploration of faculty values and needs in seven disciplines. Berkeley: University of California Center for Studies in Higher Education. ISBN: 9780615358345

https://escholarship.org/uc/item/15x7385g

Herman, Eti; Nicholas, David (2019). "Scholarly reputation building in the digital age: An activity-specific approach. Review article". El profesional de la información, v. 28, n. 1, e280102.

https://doi.org/10.3145/epi.2019.ene.02

Hollywood, Amelia; McCarthy, Daniel; Spencely, Carol; Winstone, Naomi (2020). "'Overwhelmed at first': the experience of career development in early career academics". Journal of further and higher education, v. 44, n. 7, pp. 998-1012. https://doi.org/10.1080/0309877X.2019.1636213

Jamali, Hamid R.; Nicholas, David; Watkinson, Anthony; Abrizah, Abdullah; Rodríguez-Bravo, Blanca; Boukacem-Zeghmouri, Chérifa; Xu, Jie; Polezhaeva, Tatiana; Herman, Eti; Świgon, Marzena (2020). "Early career researchers and their authorship and peer review beliefs and practices: An international study". Learned publishing, v. 33, n. 2, pp. 142-152. https://doi.org/10.1002/leap.1283

Korbel, Jan O.; Stegle, Oliver (2020). "Effects of the Covid-19 pandemic on life scientists". Genome biology, v. 21, n. 113. https://doi.org/10.1186/s13059-020-02031-1

Kwon, Diana (2020). "After conference cancellations, some scientists find a way". The scientist, March 23. https://www.the-scientist.com/news-opinion/after-conference-cancellations-some-scientists-find-a-way-67310

Langin, Katie (2020). "US faculty job market tanks". Science, v. 370, n. 6514, pp. 272-273.

https://doi.org/10.1126/science.370.6514.272

León-García, Fernando; Cherbowski-Lask, Arturo (2020). Leadership responses to Covid-19: A global survey of college and university leadership. IAUP. International Association of University Presidents and Santander Universidades. https://www.iaup.org/wp-content/uploads/2020/11/IAUP-Survey-2020-ExecutiveSummary.pdf

Levine, Felice J.; Nasir, Na'ilah-Suad; Ríos-Aguilar, Cecilia; Gildersleeve, Ryan-Evelyn; Rosich, Katherine J.; Bang, Megan; Bell, Nathan E.; Holsapple, Matthew A. (2021). Voices from the field: The impact of Covid-19 on early career scholars and doctoral students [Focus group study report]. American Educational Research Association; Spencer Foundation. https://doi.org/10.3102/aera20211 
London Economics (2020). Impact of the Covid-19 pandemic on university finances: Report for the University and College Union. April 2020.

https://londoneconomics.co.uk/blog/publication/impact-of-the-covid-19-pandemic-on-university-finances-april-2020

Maas, Bea; Grogan, Kathleen E.; Chirango, Yolanda; Harris, Nyeema; Liévano-Latorre, Luisa-Fernanda; McGuire, Krista L.; Moore, Alexandria C.; Ocampo-Ariza, Carolina; Palta, Monica-Marie; Perfecto, Ivette; Primack, Richard B.; Rowell, Kirsten; Sales, Lilian; Santos-Silva, Rejane; Silva, Rafaela-Aparecida; Sterling, Eleanor J.; Vieira, Raísa R. S.; Wyborn, Carina; Toomey, Anne (2020). "Academic leaders must support inclusive scientific communities during Covid-19". Nature ecology and evolution, n. 4, pp. 997-998.

https://doi.org/10.1038/s41559-020-1233-3

Maher, Brendan; Sureda-Anfres, Miquel (2016). "Young scientists under pressure: What the data show". Nature, v. 538, n. 7626, pp. 444-445.

https://doi.org/10.1038/538444a

McQuarrie, Fiona A. E.; Kondra, Alex Z.; Lamertz, Kai (2020). “Do tenure and promotion policies discourage publications in predatory journals?". Journal of scholarly publishing, v. 51, n. 3, pp.165-181.

https://doi.org/10.3138/jsp.51.3.01

Merton, Robert K. (1973). The sociology of science: Theoretical and empirical investigations. Chicago: The University of Chicago. ISBN: 9780226520926

Minello, Alessandra (2020). "The pandemic and the female academic". Nature, 17 April. https://doi.org/10.1038/d41586-020-01135-9

Minello, Alessandra; Martucci, Sara; Manzo, Lidia K. C. (2020). "The pandemic and the academic mothers: Present hardships and future perspectives". European societies, online first.

https://doi.org/10.1080/14616696.2020.1809690

Müller, Ruth (2014a). "Postdoctoral life scientists and supervision work in the contemporary university: A case study of changes in the cultural norms of science". Minerva, v. 52, n. 3, pp. 329-349.

https://doi.org/10.1007/s11024-014-9257-y

Müller, Ruth (2014b). "Racing for what? Anticipation and acceleration in the work and career practices of academic life science postdocs". Forum qualitative social research, v. 15, n. 3.

https://doi.org/10.17169/fqs-15.3.2245

Mulligan, Adrian; Hall, Louise; Raphael, Ellen (2013). "Peer review in a changing world: An international study measuring the attitudes of researchers". Journal of the American Society for Information Science and Technology, v. 64, n. 1, pp. $132-161$. https://doi.org/10.1002/asi.22798

Myers, Kyle R.; Tham, Wei-Yang; Yin, Yian; Cohodes, Nina; Thursby, Jerry G.; Thursby, Marie C.; Schiffer, Peter; Walsh, Joseph T.; Lakhani, Karim R.; Wang, Dashun (2020). "Unequal effects of the Covid-19 pandemic on scientists". Nature human behaviour, v. 4, n. 9, pp. 880-883.

https://doi.org/10.1038/s41562-020-0921-y

National Academy of Sciences; National Academy of Engineering; Institute of Medicine (2014). The postdoctoral experience revisited. Washington, DC: The National Academies Press. ISBN: 9780309314497

Nicholas, David; Herman, Eti; Jamali, Hamid R.; Abrizah, Abdulah; Boukacem-Zeghmouri, Chérifa; Xu, Jie; Rodríguez-Bravo, Blanca; Watkinson, Anthony; Polezhaeva, Tatiana; Świgoń, Marzena (2020b). “Millennial researchers in a metric-driven scholarly world: An international study". Research evaluation, v. 29, n. 3, pp. 263-274.

https://doi.org/10.1093/reseval/rvaa004

Nicholas, David; Herman, Eti; Jamali, Hamid R.; Rodríguez-Bravo, Blanca; Boukacem-Zeghmouri, Chérifa; Dobrowolski, Tom; Pouchot, Stephanie (2015). "New ways of building, showcasing, and measuring scholarly reputation". Learned publishing, v. 28, n. 3, pp. 169-183.

https://doi.org/10.1087/20150303

Nicholas, David; Jamali, Hamid R.; Watkinson, Anthony; Herman, Eti; Abrizah, Abdulah; Rodríguez-Bravo, Blanca; Boukacem-Zeghmouri, Chérifa; Xu, Jie; Świgoń, Marzena; Polezhaeva, Tatiana (2020a). "A global questionnaire survey of the scholarly communication attitudes and behaviours of early career researchers". Learned publishing, v. 33, n. 3, pp. $198-211$. https://doi.org/10.1002/leap.1286

Nicholas, David; Rodríguez-Bravo, Blanca; Watkinson, Anthony; Boukacem-Zeghmouri, Chérifa; Herman, Eti; Xu, Jie; Abrizah, Abdulah; Świgoń, Marzena (2017). "Early career researchers and their publishing and authorship practices". Learned publishing, v. 30, n. 3, pp. 205-217.

https://doi.org/10.1002/leap.1102 
Nicholas, David; Watkinson, Anthony; Abrizah, Abdulah; Rodríguez-Bravo, Blanca; Boukacem-Zeghmouri, Chérifa; Xu, Jie; Świgoń, Marzena; Herman, Eti (2020c). "Does the scholarly communication system satisfy the beliefs and aspirations of new researchers? Summarizing the Harbingers research". Learned publishing, v. 33, n. 2, pp. 132-141.

https://doi.org/10.1002/leap.1284

Nicholas, David; Watkinson, Anthony; Boukacem-Zeghmouri, Chérifa; Rodríguez-Bravo, Blanca; Xu, Jie; Abrizah, Abdulah; Świgoń, Marzena; Clark, David; Herman, Eti (2019). "So, are early career researchers the harbingers of change?". Learned publishing, v. 32, n. 3, pp. 237-247.

https://doi.org/10.1002/leap.1232

Olena, Abby (2020). "Covid-19 ushers in the future of conferences". The scientist, September 28.

https://www.the-scientist.com/news-opinion/covid-19-ushers-in-the-future-of-conferences-67978

Oleschuk, Merin (2020). “Gender equity considerations for tenure and promotion during Covid-19”. Canadian review of sociology, v. 57 , n. 3, pp. 502-515.

https://doi.org/10.1111/cars.12295

Pai, Madhukar (2020). "Covidization of research: What are the risks?". Nature medicine, v. 26, n. 1159. https://doi.org/10.1038/s41591-020-1015-0

Pain, Elisabeth (2020). "How early-career scientists are coping with Covid-19 challenges and fears”. Science magazine, April 17. https://doi.org/10.1126/science.caredit.abc3177

Peters, Diane (2020). "Women academics worry the pandemic is squeezing their research productivity". University affairs, July 7.

https://www.universityaffairs.ca/news/news-article/women-academics-worry-the-pandemic-is-squeezing-theirresearch-productivity

Petsko, Gregory A.; Anderson-Thompkins, Sibby; Bernard, H. Russell; Greider, Carol; Plummer, James; Reece, E. Albert; Schwartz, Nancy; Stephan, Paula; Tracey, Lorraine; Turner, Michael (2014). The postdoctoral experience revisited. Washington, DC: National Academies Press. ISBN: 9780309314466

https://doi.org/10.17226/18982

Pew Research Center (2010a). Millennials: A portrait of generation next.

https://www.pewsocialtrends.org/2010/02/24/millennials-confident-connected-open-to-change

Powell, Kendall (2015). "The future of the postdoc". Nature, v. 520, n. 7546, pp. 144-147.

https://doi.org/10.1038/520144a

Radecki, Jane; Schonfeld, Roger C. (2020). The impacts of Covid-19 on the research enterprise: A landscape review. Ithaka S+R.

https://doi.org/10.18665/sr.314247

Redden, Elizabeth (2020). "Empty benches at empty lab tables”. Inside higher ed, March 30.

https://www.insidehighered.com/news/2020/03/30/nonessential-research-has-halted-many-campuses

Rijs, Chantelle; Fenter, Frederick (2020) "The academic response to Covid-19". Frontiers in public health, n. 8. https://doi.org/10.3389/fpubh.2020.621563

Roach, Michael; Sauermann, Henry (2017). "The declining interest in an academic career". PLoS one, v. 12, n. 9, e0184130.

https://doi.org/10.1371/journal.pone.0184130

Ross, John (2020). "Pandemic's impact on Australian research 'protracted'”. Times higher education, May 11. https://www.timeshighereducation.com/news/pandemics-impact-australian-research-protracted

Sauermann, Henry; Roach, Michael (2012). "Science PhD career preferences: Levels, changes, and advisor encouragement". PloS one, v. 7, n. 5, e36307.

https://doi.org/10.1371/journal.pone.0036307

Schleunes, Amy (2020). "Universities issue hiring freezes in response to Covid-19". Science, March 26. https://www.the-scientist.com/news-opinion/universities-issue-hiring-freezes-in-response-to-covid-19-67334

Schoen, Antoine; Paradeise, Catherine; Cauchard, Lionel; Noël, Marianne (2014). “A double shift in researchers' activity profiles: An actor-based analysis of the making of quality in high standing academic departments". In: Noyons, Ed (ed.). STI 2014 Leiden: Context counts: Pathways to master big and little data. Proceedings of the science and technology indicators conference, 3-5 September 2014, Leiden, the Netherlands.

https://zenodo.org/record/2560399\#.YBkk2ZNKhBw 
SMaRteN; Vitae (2020). Release of initial findings to sector following response to Covid-19 survey, 17 May. The Student Mental Health Research Network; Vitae.

https://www.vitae.ac.uk/news/vitae-news-2020/release-of-initial-findings-to-sector-following-response-to-covid-19-survey

Smith, Chris; Watchorn, Deirdre (2020). "The pandemic is making it harder for researchers but women are hit the hardest. 4 findings from 80 countries". Impact of social sciences blog, 17 September.

https://blogs.Ise.ac.uk/impactofsocialsciences/2020/09/17/the-pandemic-is-making-it-harder-for-researchers-butwomen-are-hit-the-hardest-4-findings-from-80-countries

Squazzoni, Flaminio; Bravo, Giangiacomo; Grimaldo, Francisco; García-Costa, Daniel; Farjam, Mike; Mehmani, Bahar (2020). "No tickets for women in the Covid-19 race? A study on manuscript submissions and reviews in 2347 Elsevier journals during the pandemic". SSRN electronic journal.

https://doi.org/10.2139/ssrn.3712813

Subbaraman, Nidhi (2020). "Sputnik moment or budget breaker: How will the pandemic alter research funding?". Nature, v. 582, n. 7811, pp. 164-165.

https://doi.org/10.1038/d41586-020-01519-x

Teichler, Ulrich; Cummings, William K. (2015). "Forming, recruiting and managing the academic profession: A varied scene". In: Teichler, Ulrich; Cummings, William K. (eds). Forming, recruiting and managing the academic profession, pp. 1-10. Cham: Springer. ISBN: 9783319160801

Thatcher, Arran; Zhang, Mona; Todoroski, Hayden; Chau, Anthony; Wang, Joanna; Liang, Gang (2020). "Predicting the impact of Covid-19 on Australian universities". Journal of risk and financial management, v. 13, n. 9, p. 188. https://doi.org/10.3390/jrfm13090188

Vatansever, Asli (2020). At the margins of academia: Exile, precariousness, and subjectivity. Leiden: Brill. ISBN: 97890 04431348

Viglione, Giuliana (2020). "Are women publishing less during the pandemic? Here's what the data say". Nature, v. 581, n. 365-366.

https://doi.org/10.1038/d41586-020-01294-9

Vincent-Lamarre, Philippe; Sugimoto, Cassidy R.; Larivière, Vincent (2020a). "The decline of women's research production during the coronavirus pandemic". Nature index, v. 19.

https://www.natureindex.com/news-blog/decline-women-scientist-research-publishing-production-coronavirus-pandemic

Vincent-Lamarre, Philippe; Sugimoto, Cassidy R.; Larivière, Vincent (2020b). Monitoring women's scholarly production during the Covid-19 pandemic.

http://shiny.initiativesnumeriques.org/monitoring-scholarly-covid

Waaijer, Cathelijn J.; Belder, Rosalie; Sonneveld, Hans; Van-Bochove, Cornelis A.; Van-der-Weijden, Inge C. M. (2017). "Temporary contracts: Effect on job satisfaction and personal lives of recent PhD graduates". Higher education, v. 74, n. 2, pp. 321-339.

https://doi.org/10.1007/s10734-016-0050-8

Watchorn, Deirdre; Heckendorf, Esther; Smith, Chris (2020). Locked down, burned out: Publishing in a pandemic: The impact of Covid on academic authors. Berlin, Germany: De Gruyter.

https://blog.degruyter.com/wp-content/uploads/2020/12/Locked-Down-Burned-Out-Publishing-in-a-pandemic Dec-2020.pdf

Weissgerber, Tracey; Bediako, Yaw; De-Winde, Charlotte M.; Ebrahimi, Hedyeh; Fernández-Chiappe, Florencia; Ilangovan, Vinodh; Mehta, Devang; Paz-Quezada, Carolina; Riley, Julia L.; Saladi, Shyam M.; Sarabipour, Sarvenaz; Tay, Andy (2020). "Point of view: Mitigating the impact of conference and travel cancellations on researchers' futures". eLife, v. 9, e57032.

https://doi.org/10.7554/eLife.57032

Wigginton, Nicholas S.; Cunningham, Rebecca M.; Katz, Randy H.; Lidstrom, Mary E.; Moler, Kathryn-Ann; Wirtz, Denis; Zuber, Maria T. (2020). “Moving academic research forward during Covid-19”. Science, v. 368, n. 6496, pp.1190-1192. https://doi.org/10.1126/science.abc5599

Woolston, Chris (2020a). “Pandemic darkens postdocs' work and career hopes”. Nature, v. 585, n. 7824, pp. $309-312$. https://doi.org/10.1038/d41586-020-02548-2

Woolston, Chris (2020b). "Postdoc survey reveals disenchantment with working life". Nature, v. 587, pp. 505-508. https://doi.org/10.1038/d41586-020-03191-7

Xing, Yanmeng; Zeng, An; Fan, Ying; Di, Zengru (2019). "The strong nonlinear effect in academic dropout. Scientometrics, v. 120, n. 2, pp. 793-805.

https://doi.org/10.1007/s11192-019-03135-7 